\title{
Multiple anthelmintic resistance in Southern Brazil sheep flocks
}

\author{
Múltipla resistência anti-helmíntica em rebanhos ovinos no sul do Brasil
}

Plínio Aguiar de Oliveira ${ }^{1}$; Beatriz Riet-Correa ${ }^{2}$; Pablo Estima-Silva ${ }^{3}$; Ana Carolina Barreto Coelho ${ }^{3}$;

Bianca Lemos dos Santos ${ }^{3}$; Marco André Paldês Costa ${ }^{4}$; Jerônimo Lopes Ruas ${ }^{5}$; Ana Lucia Schild ${ }^{5 *}$

\author{
${ }^{1}$ Programa de Pós-graduação em Parasitologia, Universidade Federal de Pelotas - UFPel, Pelotas, RS, Brasil \\ ${ }^{2}$ Faculdade de Veterinária, Universidade Federal do Rio Grande do Sul - UFRGS, Porto Alegre, RS, Brasil \\ ${ }^{3}$ Programa de Pós-graduação em Veterinária, Universidade Federal de Pelotas - UFPel, Pelotas, RS, Brasil \\ ${ }^{4}$ Departamento de Matemática e Estatística, Instituto de Física e Matemática, Universidade Federal de Pelotas - UFPel, Pelotas, RS, Brasil \\ ${ }^{5}$ Laboratório Regional de Diagnóstico - LRD, Faculdade de Veterinária, Universidade Federal de Pelotas - UFPel, Pelotas, RS, Brasil
}

Received June 21, 2017

Accepted September 12, 2017

\begin{abstract}
Gastrointestinal parasites represent an important cause of reduced productivity of sheep worldwide. As anthelmintic are still the main control tool for these parasites, this work evaluated the efficacy of commercially available active principles in 22 sheep flocks in the southern region of Rio Grande do Sul, Brazil. In each farm 10 sheep were randomly distributed in seven groups with the following treatments: abamectin; albendazole; closantel; levamisole; monepantel; trichlorphon and no anthelmintic (control). All flocks showed resistance to at least three anthelmintics and in 20 farms only two products demonstrated efficacy for parasitic control. In two farms, there was no susceptibility to the six active principles tested. The results of this study provide evidence that the common commercially available anthelmintic are not assuring effective chemical control of gastrointestinal parasitic infections in ovine flocks in the southern region of Rio Grande do Sul. Monepantel, the newest introduced drug in the Brazilian market was not effective in $18 \%$ of the flocks tested, confirming that the parasitic resistance can be established quickly after the introduction of new molecules mainly when alternative program of parasite control is not performed.
\end{abstract}

Keywords: Sheep breeding, gastrointestinal nematodes, chemical control, resistance.

\section{Resumo}

As parasitoses gastrintestinais representam importante causa de queda na produtividade na ovinocultura mundial. Como a utilização de anti-helmínticos é, ainda, a principal forma de controle parasitário, o presente estudo avaliou a eficácia de princípios ativos comercialmente disponíveis, em 22 rebanhos ovinos da regiáo Sul do Rio Grande do Sul, Brasil. Em cada propriedade foram utilizados 10 ovinos divididos em sete grupos que receberam os seguintes tratamentos: abamectina; albendazole; closantel; levamisole; monepantel; e triclorfon. Um grupo permaneceu como controle, sem tratamento anti-helmíntico. Nas 22 propriedades do estudo houve resistência, no mínimo, a três anti-helmínticos. Em 20 propriedades apenas dois produtos demonstraram eficácia para o controle parasitário. Em duas propriedades não houve sensibilidade aos seis princípios ativos testados. Os resultados do presente estudo demonstraram que os anti-helmínticos disponíveis no marcado Brasileiro não asseguram um controle parasitário efetivo nos rebanhos ovinos da regiāo Sul do Rio Grande do Sul, incluindo o monepantel que foi ineficaz em 18\% dos rebanhos testados, confirmando que a resistência dos parasitos aos princípios ativos pode se estabelecer rapidamente após a introdução de novas moléculas, principalmente quando programas alternativos de controle náo são realizados.

Palavras-chave: Ovinocultura, nematoides gastrintestinais, controle químico de parasitos, resistência.

\footnotetext{
*Corresponding author: Ana Lucia Schild. Laboratório Regional de 


\section{Introduction}

In the first decade of the 21st century, Brazil reached the status of the 17th largest sheep producer in the world, with a flock of 17.3 million head (FAO, 2012). More than 3.9 million of these animals belonged to breeders in the state of Rio Grande do Sul (IBGE, 2012), a region where the activity is of great importance for the economy and provides subsistence for families from rural areas (SILVA et al., 2013). The economic expansion of sheep farming has also become a worldwide reality (VERÍSSIMO et al., 2012).

There are reports that, in the state of Rio Grande do Sul, parasitic diseases represent from $24.3 \%$ to $66.8 \%$ of the diagnoses performed in sheep flocks (RISSI et al., 2010). This includes gastrointestinal parasites, a major cause of mortality and reduced productivity in small ruminants (CHARLIER et al., 2014b). In the majority of properties, anthelmintics are still the main parasitic control tool (LARA, 2013) and indiscriminate use of anthelmintics has contributed to the selection and establishment of resistant parasites (ALMEIDA et al., 2010). This fact represents one of the greatest problems for the effective control of parasites in sheep (MOLENTO, 2004; VERÍSSIMO et al., 2012), preventing the sustainability of global sheep farming (COLES et al., 2006).

The recognition of anthelmintic resistance in flocks depends on monitoring the efficacy of the treatments (VERÍSSIMO et al., 2012). Rarely do sheep farmers suspect parasitic control failures until the onset of outbreaks with clinical signs and deaths. At that moment, however, there are already great economic losses and the propagation of parasites resistant to the active principles employed (CEZAR et al., 2010). With the purpose of monitoring anthelmintic resistance, the fecal egg count reduction test (FECRT) is recommended for convenience and low cost and is suitable for evaluating all anthelmintic groups (COLES et al., 2006).

Therefore, the objective of this work was to evaluate the efficacy of commercially available anthelmintics for the chemical control of gastrointestinal parasites of sheep in the southern region of Rio Grande do Sul, Brazil.

\section{Methods}

\section{Flock selection}

In the records of the Regional Diagnostic Laboratory, Faculty of Veterinary Medicine of the Federal University of Pelotas, rural farms in the southern region of Rio Grande do Sul with sheep breeding were consulted. After interviewing owners interested in cooperating, flocks that had not been dosed in the last 45 days were pre-selected. At the end, laboratory tests for egg counts per gram of feces (EPG) allowed the selection of 22 properties with mean EPG $\geq 300$ for at least $80 \%$ of the evaluated animals, since all the tests were performed in duplicate.

\section{Anthelminthic resistance detection}

In vivo fecal egg count reduction tests (FECRT) were performed in the period from March to July 2016, prioritizing the recommendations of the World Association for the Advancement of Veterinary Parasitology (WAAVP), regarding the detection of anthelminthic resistance (COLES et al., 1992). Thus, in each property 10 animals were randomly distributed in seven groups and randomized the following treatments: abamectin $0.2 \mathrm{mg} / \mathrm{kg}$ (Avotan ${ }^{\circledR}$, MSD Saúde Animal) body weight; albendazole $3.4 \mathrm{mg} / \mathrm{kg}$ (Endazol ${ }^{\circledR}$, Hipra); closantel $10 \mathrm{mg} / \mathrm{kg}$ (Diantel ${ }^{\circledR}$, Hipra); Levamisole $7.5 \mathrm{mg} / \mathrm{kg}$ (Ripercol L $150 \mathrm{~F}^{\circledR}$, Fort Dodge); Monepantel $2.5 \mathrm{mg} / \mathrm{kg}$ (Zolvix ${ }^{\circledR}$, Novartis); trichlorphon (TRI) $50 \mathrm{mg} / \mathrm{kg}$ (Neguvon ${ }^{\circledR}$, Bayer) and control (no anthelmintic treatment).

Fecal samples were collected directly from the rectal ampulla of each individual 14 days after the experiment was set up (D14) for EPG using the modified Gordon and Whitlock technique (UENO \& GUTIERREZ, 1983) with a sensitivity of 100 eggs.

The reduction percentage (PR) of the stool egg count was estimated by the following equation:

$$
\mathrm{PR}=100 \cdot\left(1-\overline{\mathrm{X}}_{\mathrm{t}} / \overline{\mathrm{X}}_{\mathrm{c}}\right)
$$

where $\bar{X}_{t}$ is the arithmetic mean of the egg count for the treatment group $t$, and $\bar{X}_{c}$ is the arithmetic mean for the control group, both D14. Worms are called susceptible to the active principle when (i) the PR is greater than or equal to $95 \%$ and (ii) the lower limit of the $95 \%$ confidence interval is greater than or equal to $90 \%$. If only one of these criteria is observed, the effectiveness of the anthelmintic is said to be suspected.

For each experimental group (treatment) in D14, fecal samples of all animals were combined in equal proportions for culture (UENO, 1995) in vitro and subsequent identification of the larvae (VAN WYK \& MAYHEW, 2013). The EPG count of each individual was then adjusted to the proportion of the gastrointestinal nematode genera to estimate the specific efficacy of the active principles.

All the experimental procedures were approved by the Committee of Ethics and Animal Experimentation of UFPel (Protocol CEEA no 7453-2015).

\section{Results}

The farms studied are between 18 and 6000 ha, with flocks consisting of 75 to 750 sheep. Eighteen farms used extensive breeding system and four semi-intensive breeding systems. The breed purposes varied among the 22 farms. In ten farms, sheep were raised for both meat and wool production, in seven farms for meat production, in three farms for breeding stock and meat and wool production, and in two farms for breeding stock and meat production.

Table 1 shows the percentages of reduction of fecal egg counts for each property, while the corresponding efficacy is summarized in Table 2. The specific action of the drugs against the genera of the parasites is also described in Table 3. Resistance to at least three anthelmintic agents was reported on all properties (Table 1). However, no sensitivity was reported for any of the active principles tested on two of these (11 and 22) properties. In addition, none of the other flocks (20/22) had more than two drug options to define an effective parasitic chemical control strategy. 
Table 1. Reduction percentage (PR) of fecal egg count after 14 days of anthelmintic treatment in 22 sheep flocks in the Southern Brazil.

\begin{tabular}{|c|c|c|c|c|c|c|c|c|c|c|c|c|}
\hline \multirow{2}{*}{ Flocks } & \multicolumn{11}{|c|}{ Anthelminthic } & \\
\hline & CLO & & MON & & ALB & & LEV & & ABA & & TRI & \\
\hline 1 & 87.1 & $(67.7)$ & 100.0 & - & 90.3 & $(70.4)$ & 93.5 & $(72.8)$ & 87.1 & $(67.7)$ & 67.7 & $(21.4)$ \\
\hline 2 & 84.4 & $(66.0)$ & 100.0 & - & 90.6 & $(71.2)$ & 93.8 & $(73.6)$ & 93.8 & $(73.6)$ & 78.1 & (36.9) \\
\hline 3 & 87.1 & $(45.6)$ & 100.0 & - & 90.3 & $(55.3)$ & 87.1 & $(33.6)$ & 100.0 & - & 74.2 & $(30.0)$ \\
\hline 4 & 75.5 & $(00.4)$ & 100.0 & - & 73.6 & $(-58.6)$ & 100.0 & - & 88.7 & $(68.5)$ & 96.2 & $(82.2)$ \\
\hline 5 & 84.0 & $(60.1)$ & 92.0 & $(66.4)$ & 92.0 & $(66.4)$ & 60.0 & $(25.2)$ & 100.0 & - & 68.0 & $(-56.5)$ \\
\hline 6 & 96.3 & $(83.2)$ & 96.3 & $(83.2)$ & 85.2 & $(36.2)$ & 72.2 & $(38.2)$ & 92.6 & $(59.4)$ & 100.0 & - \\
\hline 7 & 51.1 & $(-20.9)$ & 83.0 & $(44.6)$ & 38.6 & $(-95.4)$ & 65.9 & $(07.5)$ & 79.5 & (30.9) & 98.9 & $(90.4)$ \\
\hline 8 & 91.0 & $(56.3)$ & 100.0 & - & 67.2 & $(23.2)$ & 98.5 & $(87.0)$ & 76.1 & $(-01.3)$ & 95.5 & $(85.2)$ \\
\hline 9 & 83.3 & $(58.6)$ & 100.0 & - & 80.6 & $(51.4)$ & -22.2 & $(-186.6)$ & 100.0 & - & 97.2 & (76.0) \\
\hline 10 & 90.0 & $(68.3)$ & 100.0 & - & 63.3 & $(23.2)$ & 73.3 & $(36.0)$ & 96.7 & (71.5) & 73.3 & (30.4) \\
\hline 11 & 62.5 & $(-01.5)$ & 91.7 & $(65.1)$ & 54.2 & $(05.1)$ & 75.0 & $(42.7)$ & 87.5 & $(62.1)$ & 87.5 & $(42.6)$ \\
\hline 12 & 84.4 & $(58.2)$ & 100.0 & - & 31.3 & $(-76.7)$ & 59.4 & $(18.0)$ & 100.0 & - & 46.9 & $(-51.9)$ \\
\hline 13 & 85.7 & $(65.6)$ & 100.0 & - & 89.3 & $(68.3)$ & 92.9 & $(70.7)$ & 85.7 & $(65.6)$ & 85.7 & (53.7) \\
\hline 14 & 87.0 & $(40.4)$ & 100.0 & - & 52.2 & $(01.8)$ & 97.8 & (81.9) & 65.2 & $(-37.2)$ & 93.5 & (80.3) \\
\hline 15 & 83.3 & $(65.4)$ & 100.0 & - & 90.0 & (70.3) & 93.3 & $(72.5)$ & 93.3 & $(72.5)$ & 76.7 & (34.8) \\
\hline 16 & 56.7 & $(-51.5)$ & 100.0 & - & 53.3 & $(-150.0)$ & 100.0 & - & 80.0 & $(55.1)$ & 93.3 & (72.4) \\
\hline 17 & 86.7 & $(67.2)$ & 100.0 & - & 93.3 & $(72.2)$ & 66.7 & $(38.7)$ & 100.0 & - & 73.3 & $(-29.5)$ \\
\hline 18 & 76.9 & $(48.9)$ & 100.0 & - & 84.6 & $(50.2)$ & 42.3 & $(-15.2)$ & 100.0 & - & 96.2 & (68.3) \\
\hline 19 & 69.0 & $(18.6)$ & 100.0 & - & 69.0 & $(39.5)$ & 82.8 & $(55.2)$ & 89.7 & $(69.4)$ & 89.7 & $(53.4)$ \\
\hline 20 & 93.1 & (71.6) & 100.0 & - & 82.8 & (64.3) & 89.7 & (53.3) & 93.1 & (71.6) & 96.6 & $(71.5)$ \\
\hline 21 & 93.8 & (74.3) & 96.9 & $(74.2)$ & 87.5 & $(59.4)$ & 53.1 & $(15.1)$ & 87.5 & (37.1) & 100.0 & - \\
\hline 22 & 0.0 & $(-73.7)$ & 90.0 & $(54.6)$ & 73.3 & $(46.5)$ & 76.7 & $(47.3)$ & 83.3 & $(65.1)$ & 96.7 & $(72.4)$ \\
\hline
\end{tabular}

Notes: 87.1 (67.7) - > reduction percentage (lower limit of the $95 \%$ confidence interval); - ("dash") - > unavailable due to the absence of variance for the OPG. Susceptible: PR is greater than or equal to $95 \%$ and the lower limit of the $95 \%$ confidence interval is greater than or equal to $90 \%$. If only one of these criteria is observed, the effectiveness of the anthelmintic is said to be suspected. CLO: closantel $10 \mathrm{mg} / \mathrm{kg}$ body weight; MON: monepantel $2.5 \mathrm{mg} / \mathrm{kg}$; ALB: albendazole 3.4mg/kg; LEV: levamisole $7.5 \mathrm{mg} / \mathrm{kg}$; ABA: abamectin $0.2 \mathrm{mg} / \mathrm{kg}$; TRI: trichlorphon $50 \mathrm{mg} / \mathrm{kg}$.

Table 2. Number of farms (\% of total) found to be susceptible, resistant or suspected of resistance to the different anthelmintics used in a survey in 22 sheep flocks in Southern Brazil.

\begin{tabular}{|c|c|c|c|c|c|c|c|c|c|c|c|c|c|c|}
\hline \multirow{2}{*}{ Efficacy } & \multicolumn{12}{|c|}{ Anthelminthic } & \multirow{2}{*}{\multicolumn{2}{|c|}{ Total }} \\
\hline & CLO & & MON & & ALB & & LEV & & ABA & & TRI & & & \\
\hline Susceptible & 0 & $(0.00)$ & 16 & $(0.73)$ & 0 & $(0.00)$ & 2 & $(0.09)$ & 6 & $(0.27)$ & 3 & $(0.14)$ & 27 & $(0.205)$ \\
\hline Resistant & 21 & $(0.95)$ & 4 & $(0.18)$ & 22 & $(1.00)$ & 18 & $(0.82)$ & 15 & $(0.68)$ & 13 & $(0.59)$ & 93 & $(0.705)$ \\
\hline Suspected & 1 & $(0.05)$ & 2 & $(0.09)$ & 0 & $(0.00)$ & 2 & $(0.09)$ & 1 & $(0.05)$ & 6 & $(0.27)$ & 12 & $(0.091)$ \\
\hline
\end{tabular}

Notes: $21(0.95)->$ Absolute frequency (adjusted relative frequency). CLO: closantel 10mg/kg body weight; MON: monepantel 2.5mg/kg; ALB: albendazole $3.4 \mathrm{mg} / \mathrm{kg}$; LEV: levamisole $7.5 \mathrm{mg} / \mathrm{kg}$; ABA: abamectin $0.2 \mathrm{mg} / \mathrm{kg}$; TRI: trichlorphon $50 \mathrm{mg} / \mathrm{kg}$.

Regardless of the active principle, in only $20.5 \%$ of the FECRT were the parasites susceptible to the anthelmintics tested (Table 2), excluding those suspected ones (9.1\%). In 16 cases where the drug had effective action in parasite control, the animals were dosed with monepantel. In three farms where there was resistance to monepantel and this active principle had been used previously, the selective treatment, EPG and FECRT, were not applied. In another farm where there was no report of the previous use of this active principle and there was resistance to monepantel, the selective treatment (FAMACHA) was applied, EPG was performed every six months and FECRT every 12 months. Suspicion of resistance to monepantel was observed in two farms where the selective treatment, EPG and FECRT were not applied and also there was no report of previous use of this active principle.
Although some tests have also identified parasites susceptible to abamectin, levamisole and trichlorphon, flocks prevail with resistant parasites to these last three drugs. There is no doubt about this condition for those treated with albendazole.

Larvae of Haemonchus, Oesophagostomum, Trichostrongylus and Teladorsagia represented, on average, $41.1 \%, 31.8 \%, 18.7 \%$ and $8.3 \%$, respectively, of the nematodes identified in the fecal cultures of the control groups. However, to estimate the specific efficacy of the active principles (Table 3), the presence of these larvae in each stool culture of the control group is necessary, a restriction imposed by the PR equation itself.

Thus, when comparing these results with nonspecific efficacy (Table 2), the data suggested that cases of drug-specific insensitivity are mainly due to the high prevalence of resistant strains of Haemonchus and Trichostrongylus, since these genera represented, 
Table 3. Specific efficacy of anthelmintic submitted to the fecal egg count reduction test and fecal culture in 22 sheep flocks of the Southern Brazil.

\begin{tabular}{|c|c|c|c|c|c|c|c|c|c|c|c|c|c|c|}
\hline \multirow{3}{*}{$\begin{array}{c}\text { Eficacy } \\
\text { Susceptible }\end{array}$} & \multicolumn{12}{|c|}{ Haemonchus } & \multirow{2}{*}{\multicolumn{2}{|c|}{ Total }} \\
\hline & \multirow{2}{*}{$\begin{array}{c}\text { CLO } \\
0\end{array}$} & \multicolumn{3}{|c|}{ MON } & \multirow{2}{*}{$\begin{array}{c}\text { ALB } \\
1\end{array}$} & \multicolumn{3}{|c|}{ LEV } & \multirow{2}{*}{$\begin{array}{c}\text { ABA } \\
7\end{array}$} & \multicolumn{3}{|c|}{ TRI } & & \\
\hline & & $(0.00)$ & 21 & $(0.95)$ & & $(0.05)$ & 5 & $(0.23)$ & & $(0.32)$ & 4 & $(0.18)$ & 38 & $(0.29)$ \\
\hline Resistant & 21 & $(0.95)$ & 0 & $(0.00)$ & 21 & $(0.95)$ & 17 & $(0.77)$ & 14 & $(0.64)$ & 15 & $(0.68)$ & 88 & $(0.67)$ \\
\hline Suspected & 1 & $(0.05)$ & 1 & $(0.05)$ & 0 & $(0.00)$ & 0 & $(0.00)$ & 1 & $(0.05)$ & 3 & $(0.14)$ & 6 & $(0.05)$ \\
\hline \multirow{2}{*}{ Eficacy } & \multicolumn{12}{|c|}{ Oesophagostomum } & \multirow{2}{*}{\multicolumn{2}{|c|}{ Total }} \\
\hline & CLO & & MON & & ALB & & LEV & & $\mathrm{ABA}$ & & TRI & & & \\
\hline Susceptible & 9 & $(0.50)$ & 18 & $(1.00)$ & 17 & $(0.94)$ & 17 & $(0.94)$ & 18 & $(1.00)$ & 8 & $(0.44)$ & 87 & $(0.81)$ \\
\hline Resistant & 6 & $(0.33)$ & 0 & $(0.00)$ & 1 & $(0.06)$ & 1 & $(0.06)$ & 0 & $(0.00)$ & 7 & $(0.39)$ & 15 & $(0.14)$ \\
\hline Suspected & 3 & $(0.17)$ & 0 & $(0.00)$ & 0 & $(0.00)$ & 0 & $(0.00)$ & 0 & $(0.00)$ & 3 & $(0.17)$ & 6 & $(0.06)$ \\
\hline \multirow{2}{*}{ Eficacy } & \multicolumn{12}{|c|}{ Trichostrongylus } & \multirow{2}{*}{\multicolumn{2}{|c|}{ Total }} \\
\hline & CLO & & MON & & ALB & & LEV & & ABA & & TRI & & & \\
\hline Susceptible & 3 & $(0.14)$ & 20 & $(0.91)$ & 4 & $(0.18)$ & 5 & $(0.23)$ & 9 & $(0.41)$ & 6 & $(0.27)$ & 47 & $(0.36)$ \\
\hline Resistant & 18 & $(0.82)$ & 2 & $(0.09)$ & 18 & $(0.82)$ & 16 & $(0.73)$ & 12 & $(0.55)$ & 12 & $(0.55)$ & 78 & $(0.59)$ \\
\hline Suspected & 1 & $(0.05)$ & 0 & $(0.00)$ & 0 & $(0.00)$ & 1 & $(0.05)$ & 1 & $(0.05)$ & 4 & $(0.18)$ & 7 & $(0.05)$ \\
\hline \multirow{2}{*}{ Eficacy } & \multicolumn{12}{|c|}{ Teladorsagia } & \multirow{2}{*}{\multicolumn{2}{|c|}{ Total }} \\
\hline & CLO & & MON & & ALB & & LEV & & ABA & & TRI & & & \\
\hline Susceptible & 13 & $(0.93)$ & 14 & $(1.00)$ & 13 & $(0.93)$ & 13 & $(0.93)$ & 14 & $(1.00)$ & 14 & $(1.00)$ & 81 & $(0.96)$ \\
\hline Resistance & 1 & $(0.07)$ & 0 & $(0.00)$ & 1 & $(0.07)$ & 1 & $(0.07)$ & 0 & $(0.00)$ & 0 & $(0.00)$ & 3 & $(0.04)$ \\
\hline Suspected & 0 & $(0.00)$ & 0 & $(0.00)$ & 0 & $(0.00)$ & 0 & $(0.00)$ & 0 & $(0.00)$ & 0 & $(0.00)$ & 0 & $(0.00)$ \\
\hline
\end{tabular}

Note: 21 (0.95) -> Absolute frequency (adjusted relative frequency). CLO: closantel 10mg/kg body weight; MON: monepantel 2.5mg/kg; ALB: albendazole $3.4 \mathrm{mg} / \mathrm{kg}$; LEV: levamisole $7.5 \mathrm{mg} / \mathrm{kg}$; ABA: abamectin $0.2 \mathrm{mg} / \mathrm{kg}$; TRI: trichlorphon $50 \mathrm{mg} / \mathrm{kg}$.

on average $59.9 \%$ of the flock parasitic load. In a few cases, strains of Teladorsagia were resistant to closantel, albendazole and levamisole. For the genus Oesophagostomum, there was a higher proportion of isolates insensitive to closantel and cases of resistance to trichlorphon.

\section{Discussion}

The results observed here demonstrate a worrying situation for sheep production in the southern region of the State of Rio Grande do Sul. Strong evidence suggests resistance of gastrointestinal parasites to the main commercially available anthelmintic agents, either by the criteria of Coles et al. (1992) or Brazilian legislation (BRASIL, 1997). This will become worse as none of the monitored properties have more than two drug options to define an effective chemical parasitic control strategy. There is no doubt that this scenario should also be a concern for other regions (GETACHEW et al., 2007; VÁRADY et al., 2011; CORNELIUS et al., 2014; FALZON et al., 2014), especially for those countries that border the state (Argentina and Uruguay).

Previous studies have also reported anthelmintic resistance in 97\% of properties in Rio Grande do Sul. Albendazole resistance was reported on $90 \%$ of properties; levamisole resistance was reported on $84 \%$ of properties; and a combination of albendazole and levamisole resistance was reported on $73 \%$ of properties (ECHEVARRIA et al., 1996). In addition, the resistance to avermectins, benzimidazoles and imidazothiazoles is not uncommon in Brazil (ALMEIDA et al., 2010; FARIAS et al., 1997; WALLER et al., 1996). Other studies in Brazil have shown anthelmintic resistance to different active principles such as levamisole, moxidectin, albendazole, ivermectim, nitroxynil, disophenol, trichlorphon and closantel (CEZAR et al., 2010; SCZESNY-MORAES et al., 2010; ALMEIDA et al., 2010; VERÍSSIMO et al., 2012). Monepantel was not included in these studies since it was introduced in Brazil in 2012.

The animals in this study that did not receive anthelmintic treatment (control group) were not subjected to a pre-selection of their gastrointestinal parasites, which allows a better estimate of the corresponding population proportions of the nematode genera in the flocks. In contrast, the predominance of Haemonchus and Trichostrongylus is also frequently reported in studies conducted in Brazil (MELO et al., 2009; SCZESNY-MORAES et al., 2010; VERÍSSIMO et al., 2012). Particularly for the studied region, these parasites maintain a relatively homogeneous distribution throughout the year (ECHEVARRIA \& PINHEIRO, 1989). This reinforces the concern about the contribution of these genera to the anthelmintic resistance status observed.

Monepantel, a derivative of aminoacetonitrile, is the most recent alternative in the chemical control of gastrointestinal parasites in sheep (HOSKING et al., 2010; KAMINSKY et al., 2011; SAGER et al., 2012). However, after three years of commercialization, it has already demonstrated resistant cases in New Zealand (SCOTT et al., 2013), Uruguay (MEDEROS et al., 2014) and the Netherlands (VAN DEN BROM et al., 2015). More recently, the first case of resistance was reported in Brazil (CINTRA et al., 2016). The results of the present study demonstrate that resistance to monepantel occurred mainly in the farms that did not take any action aiming at delaying the resistance. However, the resistance also occurred in a farm that performed alternative strategies for parasitic control such as selective treatment 
(FAMACHA), EPG and FECRT. In this case resistance probably was established from purchased sheep previously infected by resistant parasites. It has been mentioned that alternative strategies are required to delay the onset of anthelmintic resistance to active principles (FORTES \& MOLENTO, 2013).

Since the identification of new molecules does not accompany the unrestrained expansion of the cases of resistance, the means of dissemination of the scientific community and the development agencies should encourage publications that suggest good or innovative management practices to effectively control parasitic gastroenteritis in sheep.

Information on the biological cycle of helminths and climatic and economic conditions of each region should be considered when establishing parasitic control strategies. The use of ocular mucosa color (FAMACHA), parasite load on fecal examination, and weight gain of animals (COSTA et al., 2011; CHARLIER et al., 2014a) may also help to identify the best time for a chemical intervention. Other options include integrated management practices with the intention of minimizing the effects of parasitic infection through strategic and selective treatment schemes (HAMMERSCHMIDT et al., 2012). However, these technologies need to be encouraged more for wider acceptance among animal health producers and practitioners, which would avoid the indiscriminate use of ineffective drugs.

\section{Conclusion}

The results of this study provide evidence that the common commercially available anthelmintics are not assuring effective chemical control of gastrointestinal parasitic infections in ovine flocks in the southern region of Rio Grande do Sul. Monepantel the anthelmintic drug introduced in the Brazilian market was not effective in $18 \%$ of the tested flocks, confirming that parasitic resistance can be established very soon after the anthelmintic treatment with new molecules, mainly when alternative program of parasite control is not performed.

\section{References}

Almeida FA, Garcia KCOD, Torgerson PR, Amarante AFT. Multiple resistance to anthelmintics by Haemonchus contortus and Trichostrongylus colubriformis in sheep in Brazil. Parasitol Int 2010; 59(4): 622-625. PMid:20887800. http://dx.doi.org/10.1016/j.parint.2010.09.006.

Brasil. Ministério da Agricultura Pecuária e Abastecimento - MAPA. Portaria No 48/97. Regulamento técnico para licenciamento elou renovação de licença de produtos antiparasitários de uso veterinário [online]. Brasília: MAPA; 1997 [cited 2016 Oct 9]. Available from: http://sistemasweb. agricultura.gov.br/sislegis/action/detalhaAto.do?method=visualizarAtoP ortalMapa\&chave $=72818869$

Cezar AS, Toscan G, Camillo G, Sangioni LA, Ribas HO, Vogel FSF. Multiple resistance of gastrointestinal nematodes to nine different drugs in a sheep flock in southern Brazil. Vet Parasitol 2010; 173(1-2): 157160. PMid:20619543. http://dx.doi.org/10.1016/j.vetpar.2010.06.013.

Charlier J, Morgan ER, Rinaldi L, van Dijk J, Demeler J, Höglund J, et al. Practices to optimise gastrointestinal nematode control on sheep, goat and cattle farms in Europe using targeted (selective) treatments. Vet Rec 2014a; 13(10): 250-255. PMid:25217603. http://dx.doi.org/10.1136/ vr.102512.

Charlier J, Van der Voort M, Kenyon F, Skuce P, Vercruysse J. Chasing helminths and their economic impact on farmed ruminants. Trends Parasitol 2014b; 30(7): 361-367. PMid:24888669. http://dx.doi.org/10.1016/j. pt.2014.04.009.

Cintra MCR, Teixeira VN, Nascimento LV, Sotomaior CS. Lack of efficacy of monepantel against Trichostrongylus colubriformis in sheep in Brazil. Vet Parasitol 2016; 216: 4-6.

Coles GC, Bauer C, Borgsteede FHM, Geerts S, Klei TR, Taylor MA, et al. World Association for the Advancement of Veterinary Parasitology (W.A.A.V.P.) methods for the detection of anthelmintic resistance in nematodes of veterinary importance. Vet Parasitol 1992; 44(1-2): 35-44. PMid:1441190. http://dx.doi.org/10.1016/0304-4017(92)90141-U.

Coles GC, Jackson F, Pomroy WE, Prichard RK, von Samson-Himmelstjerna G, Silvestre A, et al. The detection of anthelmintic resistance in nematodes of veterinary importance. Vet Parasitol 2006; 136(3-4): 167185. PMid:16427201. http://dx.doi.org/10.1016/j.vetpar.2005.11.019.

Cornelius MP, Jacobson C, Besier RB. Body condition score as a selection tool for targeted selective treatment-based nematode control strategies in Merino ewes. Vet Parasitol 2014; 206(3-4): 173-181. PMid:25466620. http://dx.doi.org/10.1016/j.vetpar.2014.10.031.

Costa VMM, Simôes SVD, Riet-Correa F. Controle das parasitoses gastrintestinais em ovinos e caprinos na região semiárida do Nordeste do Brasil. Pesq Vet Bras 2011; 31(1): 65-71. http://dx.doi.org/10.1590/ S0100-736X2011000100010.

Echevarria F, Borba MFS, Pinheiro AC, Waller PJ, Hansen JW. The prevalence of anthelmintic resistance in nematode parasites of sheep in Southern Latin America: Brazil. Vet Parasitol 1996; 62(3-4): 199-206. PMid:8686165. http://dx.doi.org/10.1016/0304-4017(95)00906-X.

Echevarria F, Pinheiro A. Avaliaçáo de resistência anti-helmíntica em rebanhos ovinos no município de Bagé, RS. Pesq Vet Bras 1989; 9(3-4): 69-71.

Falzon LC, O’Neill TJ, Menzies PI, Peregrine AS, Jones-Bitton A, Van Leeuwen J, et al. A systematic review and meta-analysis of factors associated with anthelmintic resistance in sheep. Prev Vet Med 2014; 117(2): 388-402. PMid:25059197. http://dx.doi.org/10.1016/j.prevetmed.2014.07.003.

Farias MT, Bordin EL, Forbes AB, Newcomb K. A survey on resistance to anthelmintics in sheep stud farms of southern Brazil. Vet Parasitol 1997; 72(2): 209-214. PMid:9404847. http://dx.doi.org/10.1016/ S0304-4017(97)01111-4.

Food and Agriculture Organization of the United States - FAO. Global livestock production systems [online]. Rome: FAO; 2012 [cited 2016 Dec 18]. Available from: http://kids.fao.org/glipha/

Fortes FS, Molento MB. Resistência anti-helmíntica em nematoides gastrintestinais de pequenos ruminantes: avanços e limitaçóes para seu diagnóstico. Pesq Vet Bras 2013; 33(12): 1391-1402. http://dx.doi. org/10.1590/S0100-736X2013001200001.

Getachew T, Dorchies P, Jacquiet P. Trends and challenges in the effective and sustainable control of Haemonchus contortus infection in sheep. Parasite 2007; 14(1):3-14. PMid:17432053. http://dx.doi.org/10.1051/ parasite/2007141003.

Hammerschmidt J, Bier D, Fortes FS, Warzensaky P, Bainy AM, Macedo AAS, et al. Avaliaçáo do sistema integrado de controle parasitário em uma criaçáo semi-intensiva de caprinos na regiáo de Santa Catarina. Arq 
Bras Med Vet Zootec 2012; 64(4): 927-934. http://dx.doi.org/10.1590/ S0102-09352012000400020.

Hosking BC, Kaminsky R, Sager H, Rolfe PF, Seewald W. A pooled analysis of the efficacy of monepantel, an amino-acetonitrile derivative against gastrointestinal nematodes of sheep. Parasitol Res 2010; 106(2): 529-532. PMid:19795134. http://dx.doi.org/10.1007/s00436-009-1636-1.

Instituto Brasileiro de Geografia e Estatística - IBGE [online]. 2012 [cited 2016 Oct 9]. Available from: http://www.sidra.ibge.gov.br

Kaminsky R, Bapst B, Stein PA, Strehlau GA, Allan BA, Hosking BC, et al. Differences in efficacy of monepantel, derquantel and abamectin against multiresistent nematodes of sheep. Parasitol Res 2011; 109(1): 19-23. PMid:21161271. http://dx.doi.org/10.1007/s00436-010-2216-0.

Lara DM. Resistencia a los antihelmínticos: origen, desarrollo y control. Rev Corpoica 2013; 4(1): 55-71. http://dx.doi.org/10.21930/rcta. vol4_num1_art:14.

Mederos AE, Ramos Z, Banchero GE. First report of monepantel Haemonchus contortus resistance on sheep farms in Uruguay. Parasit Vectors 2014; 7(1): 598. PMid:25515711. http://dx.doi.org/10.1186/ s13071-014-0598-z.

Melo ACFL, Bevilaqua CML, Reis IF. Resistência aos anti-helmínticos benzimidazóis em nematóides gastrintestinais de pequenos ruminantes do semiárido nordestino brasileiro. Ciênc Anim Bras 2009; 10(1): 294-300.

Molento MB. Resistência de helmintos em ovinos e caprinos. Rev Bras Parasitol Vet 2004; 13(S1): 82-87.

Rissi DR, Pierezan F, Oliveira JC Fo, Fighera RA, Irigoyen LF, Kommers GD, et al. Doenças de ovinos da região central do Rio Grande do Sul: 361 casos. Pesq Vet Bras 2010; 30(1): 21-28. http://dx.doi.org/10.1590/ S0100-736X2010000100004.

Sager H, Bapst B, Strehlau GA, Kaminsky R. Efficacy of monepantel, derquantel and abamectin against adult stages of a multi-resistant Haemonchus contortus isolate. Parasitol Res 2012; 111(5): 2205-2207. PMid:22576857. http://dx.doi.org/10.1007/s00436-012-2949-z.
Scott I, Pomroy WE, Kenyon PR, Smith G, Adlington B, Moss A. Lack of efficacy of monepantel against Teladorsagia circumcincta and Trichostrongylus colubriformis. Vet Parasitol 2013; 198(1-2): 166-171. PMid:23953148. http://dx.doi.org/10.1016/j.vetpar.2013.07.037.

Sczesny-Moraes EA, Bianchin I, Silva KF, Catto JB, Honer MR, Paiva F. Resistência anti-helmíntica de nematóides gastrintestinais em ovinos, Mato Grosso do Sul. Pesq Vet Bras 2010; 30(3): 229-236. http://dx.doi. org/10.1590/S0100-736X2010000300007.

Silva APSP, Santos DV, Kohek I Jr, Machado G, Hein HE, Vidor ACM, et al. Ovinocultura do Rio Grande do Sul: descrição do sistema produtivo e dos principais aspectos sanitários e reprodutivos. Pesq Vet Bras 2013; 33(12): 1453-1458. http://dx.doi.org/10.1590/S0100-736X2013001200010.

Ueno H, Gutierrez VC. Manual para o diagnóstico das helmintoses de ruminantes. Tokyo, Japan: JICA; 1983.

Ueno H. Cultivo quantitativo de larvas de nematódeos gastrintestinais de ruminantes com tentativa para pré-diagnóstico. Tokyo, Japan: JICA; 1995.

Van Den Brom R, Moll L, Kappert C, Vellema P. Haemonchus contortus resistance to monepantel in sheep. Vet Parasitol 2015; 209(3-4): 278 280. PMid:25770852. http://dx.doi.org/10.1016/j.vetpar.2015.02.026.

Van Wyk JA, Mayhew E. Morphological identification of parasitic nematode infective larvae of small ruminants and catttle: a practical lab guide. Onderstepoort J Vet Res 2013; 80(1): 539.

Várady M, Papadopoulos E, Dolinská M, Königová A. Anthelmintic resistance in parasites of small ruminants: sheep versus goats. Helminthologia 2011; 48(3): 137-144. http://dx.doi.org/10.2478/s11687-011-0021-7.

Veríssimo CJ, Niciura SC, Alberti AL, Rodrigues CF, Barbosa CM, Chiebao DP, et al. Multidrug and multispecies resistance in sheep flocks from São Paulo state Brazil. Vet Parasitol 2012; 187(1-2): 209-216. PMid:22341829. http://dx.doi.org/10.1016/j.vetpar.2012.01.013.

Waller PJ, Echevarria F, Eddi C, Maciel S, Nari A, Hansen JW. The prevalence of anthelmintic resistance in nematode parasites of sheep in Southern Latin America: general overview. Vet Parasitol 1996; 62(3-4): 181187. PMid:8686163. http://dx.doi.org/10.1016/0304-4017(95)00909-4. 